\title{
Development of a real time PCR assay for rapid detection of Vibrio parahaemolyticus from seafood
}

\author{
Bin Liu, Xiaohua He, Wanyi Chen, Shuijing Yu, Chunlei Shi, Xiujuan Zhou, Jing Chen, Dapeng Wang, \\ Xianming Shi ${ }^{\circledR}$
}

MOST-USDA Joint Research Center for Food Safety and Bor Luh Food Safety Center, School of Agriculture and Biology, Shanghai Jiao Tong University, Shanghai 200240, China

$\triangle$ Correspondence: xmshi@sjtu.edu.cn

Received December 26, 2011 Accepted January 9, 2012

\begin{abstract}
A real time PCR assay for the detection of Vibrio parahaemolyticus in seafood samples was developed using a novel specific target and a competitive internal amplification control (IAC). The specificity of this assay was evaluated using 390 bacterial strains including $V$. parahaemolyticus, and other strains belonging to Vibrio and non-Vibrio species. The real time PCR assay unambiguously distinguished $V$. parahaemolyticus with a detection sensitivity of $4.8 \mathrm{fg}$ per PCR with purified genomic DNA or 1 CFU per reaction by counting $V$. parahaemolyticus colonies. The assays of avoiding interference demonstrated that, even in the presence of $2.1 \mu \mathrm{g}$ genomic DNA or $10^{7}$ CFU background bacteria, $v$. parahaemolyticus could still be accurately detected. In addition, the IAC was used to indicate false-negative results, and lower than 94 copies of IAC per reaction had no influence on the detection limit. Ninety-six seafood samples were tested, of which $58(60.4 \%)$ were positive, including 3 false negative results. Consequently, the real time PCR assay is effective for the rapid detection of $V$. parahaemotyticus contaminants in seafood.
\end{abstract}

KEYWORDS Vibrio parahaemolyticus, real time PCR, internal amplification control, seafood

\section{INTRODUCTION}

Vibrio parahaemolyticus is an important food-borne pathogen widely distributed in marine and estuarine environments, which can cause gastroenteritis through consumption of the raw, undercooked or mishandled seafood. This pathogen has been an increasing concern and become the largest percentage of bacterial food poisoning in littoral provinces of China (Wang et al., 2007). Its detection still depends on traditional culture methods, which are labor-intensive, complicated and time-consuming (Luan et al., 2007). Therefore, it is necessary to develop methods for rapid and accurate detection of $V$. parahaemolyticus from seafood.

Real time PCR is a widely accepted method for detection and quantification of several food-borne pathogens. Although this method is highly sensitive, the risk of false-negative results is still one limitation that cannot be overlooked (Maaroufi et al., 2006), which may be due to the presence of inhibitory factors, including food residues, organic solvents from nucleic acid extraction, or other unknown factors (Kreader, 1996; Abu Al-Soud and Rådström, 1998; Al-Soud and Rådström, 2001; Maaroufi et al., 2004). To address this challenge, another nucleic acid sequence was suggested to serve as an internal amplification control (IAC) and monitor amplification processes during PCR (Rosenstraus et al., 1998; Courtney et al., 1999; Niesters, 2004; Hartman et al., 2005; Raggam et al., 2005) and distinguish false-negative from true-negative results.

The non-competitive IACs were initially used to avoid false-negative results in previous PCR detection systems (Blackstone et al., 2007; Nordstrom et al., 2007). The disadvantage of non-competitive IACs is that amplification may not reflect the primary target accurately, because of differences in amplification efficiency and relative abundance of targets and IACs. Moreover, there is another disadvantage that fails to 
avoid the interferences between the target primers and IAC primers, which may often be less efficient for one or both reactions (Hoorfar et al., 2004). To overcome these disadvantages, some factors must be carefully considered, such as the nucleotide compositions of the target and IAC, the length of the IAC, and the amplification efficiency of primers.

In addition, detection targets of $V$. parahaemolyticus lack specificity, such as gyrB, thh, tdh, trh, groEL and toxR genes (Miller et al., 1987; Shirai et al., 1990; Tada et al., 1992; Venkateswaran et al., 1998; Bej et al., 1999; Kim et al., 1999; Luan et al., 2007; Hossain et al., 2012). Consequently, it is necessary to identify other target sequences, which show no or low similarity to other bacterial species, but exhibit high specificity for $V$. parahaemolyticus.

In this study, a bioinformatics approach was applied to identify a more specific target sequence of $V$. parahaemolyticus. Real time PCR was then employed with a competitive IAC to detect this pathogen in seafood.

\section{RESULTS}

\section{Real time PCR: specificity, sensitivity, and standard curve}

Specificity of the real time PCR was evaluated among 390 strains. To consistently collect and analyze data, the baseline and threshold of PCR amplification profiles were set to the same for all the targets. As shown in Table 1, only V. parahaemolyticus strains produced a positive fluorescent signal, with $C_{t}$ values between 17 and 20 . The other bacteria tested were negative with only IAC signals.

The detection limit of the assay was $4.8 \mathrm{fg}$ per reaction using the templates of purified $V$. parahaemolyticus ATCC33846 genomic DNA. As the template DNA concentration decreased, the target $C_{t}$ value increased (Table $S 1$ in supplementary data). For pure cultures of $V$. parahaemolyticus, PCR was capable of detecting as low as $1.61 \times 10^{2} \mathrm{CFU} / \mathrm{mL}$ (about $1 \mathrm{CFU}$ from a pure culture per reaction) per reaction. The $C_{t}$ value for the targeted gene increased as the concentration of target bacteria decreased (Table S2 in supplementary data).

Standard curves showed that there was a good linear correlation between the $C_{t}$ values and the concentrations of added genomic DNA or bacteria, as the $R^{2}$ values for the purified DNA and bacterial cultures were 0.998 and 0.993 , respectively.

\section{Influence of background non-V. parahaemolyticus DNA or bacteria}

When $2.4 \mathrm{ng}-0.24 \mathrm{fg}$ of purified $V$. parahaemolyticus genomic DNA was tested with a background of $2.1 \mu \mathrm{g}$ non- $V$. parahaemolyticus bacterial DNA, the $C_{t}$ values increased by approximately one cycle or less as compared to the $C_{t}$ values obtained without background DNA (Table 2). However, the increase was not statistically significant $(p>0.05)$, implying that no significant inhibition to the target reaction occurred in the presence of $2.1 \mu \mathrm{g}$ of background DNA. When background DNA was included at levels below $2.1 \mu \mathrm{g}$, no notable change in the $C_{t}$ value was observed (data not shown).

The presence of non- $V$. parahaemolyticus ( $V$. vulnificus, $V$. alginolyticus, and $V$. harveyi) background bacteria at a level of $10^{7}$ CFU had no effect on the sensitivity of detection of $V$. parahaemolyticus, although the $C_{t}$ values did increase slightly but not significantly $(p>0.05)$ compared to PCRs without background bacteria (Table 3 ).

\section{Detection of $V$. parahaemolyticus in naturally contami- nated seafood samples}

Ninety-six seafood samples selected randomly from local markets were tested for the presence of $V$. parahaemolyticus. The results showed that 55 samples $(57.3 \%)$ were identified as positive using the real time PCR assay, while only 39 positive samples were detected with traditional culture methods. Among the negative samples, five seafood samples were categorized as false-negative (i.e. absence of the amplification signal for both IAC and target DNAs), indicating the absence of PCR inhibitors (Table 4). The results were verified with 5-fold serially diluted template DNAs of the five false-negative samples. Three of the five samples were then positive for $V$. parahaemolyticus, while two samples remained negative. Therefore, 58 samples were positive.

\section{DISCUSSION}

Thus far, most of the target genes used in PCR detection of $V$. parahaemolyticus encode proteins involved in virulence. When these genes are aligned with genomic sequences of foodborne pathogens in the NCBI genome databank, some of them have similar sequences to other Vibrio species, such as groEL, gyrB and toxR genes, while others do not exist in some strain of this pathogen, such as $t / h$, $t d h$ and trh gene. In this study, a new gene, VP1332, which encodes the binding protein component of the $A B C$ transporter, was identified using comparative genomic methods. Specificity of this gene has been verified using the PCR method to detect 390 strains of $V$. parahaemolyticus and other genus/species from clinic, food and environment samples.

In previous reports, a non-competitive IAC was used to indicate PCR inhibition with two pairs of primers being complementary to both the target DNA and non-target DNA (Nordstrom et al., 2007). However, it is difficult to avoid the interference among the primer sets or to optimize reaction conditions for all the primer sets. Therefore, a competitive IAC used for real time PCR detection was developed in this study, which could more effectively indicate false-negative results. The competitive IAC contained the same primer rec- 
Table 1 Bacterial strains used and the detection results

\begin{tabular}{|c|c|c|}
\hline Bacterial species & No. of strains studied & No. of positive results by real time PCR \\
\hline Vibrio parahaemolyticus ATCC17802 & $1^{\mathrm{a}}$ & 1 \\
\hline V. parahaemolyticus ATCC33846 & $1^{\mathrm{a}}$ & 1 \\
\hline V. parahaemolyticus & $307^{b}$ & 307 \\
\hline V. vulnificus ATCC 27562 & $1^{\mathrm{a}}$ & 0 \\
\hline V. harveyi АТСС 33842 & $1^{\mathrm{a}}$ & 0 \\
\hline V. mimicus ATCC 33653 & $1^{\mathrm{a}}$ & 0 \\
\hline V. fluvialis ATCC 33810 & $1^{\mathrm{a}}$ & 0 \\
\hline V. anguillarum & $1^{\mathrm{c}}$ & 0 \\
\hline V. damsel & $2^{c}$ & 0 \\
\hline V. campbeffi ATCC 33863 & $1^{\mathrm{a}}$ & 0 \\
\hline V. alginolyticus & $2^{c}$ & 0 \\
\hline V. cholerae ATCC25871 & $1^{\mathrm{a}}$ & 0 \\
\hline$S G L^{*}$ & $1^{\mathrm{c}}$ & 0 \\
\hline Staphylococcus aureaus & $12^{\mathrm{c}}$ & 0 \\
\hline Salmonella Typhimurium ATCC14028 & $1^{\mathrm{a}}$ & 0 \\
\hline S.Typhimurium ATCC13311 & $1^{\text {a }}$ & 0 \\
\hline S. Arizonae ATCC13314 & $1^{\mathrm{a}}$ & 0 \\
\hline S. Paratyphi A ATCC9150 & $1^{\mathrm{a}}$ & 0 \\
\hline S. Paratyphi B CMCC50004 & $1^{\mathrm{a}}$ & 0 \\
\hline S. Paratyphi C CMCC50017 & $1^{\mathrm{a}}$ & 0 \\
\hline S. Enteritidis ATCC13076 & $1^{\mathrm{a}}$ & 0 \\
\hline S. Vellore ATCC15611 & $1^{\mathrm{a}}$ & 0 \\
\hline S. Tallahassee ATCC12002 & $1^{\mathrm{a}}$ & 0 \\
\hline S. Abaetetuba CMCC51812 & $1^{\mathrm{a}}$ & 0 \\
\hline S. Choleraesuis ATCC10708 & $1^{\mathrm{a}}$ & 0 \\
\hline S. Infantis CMCC51741 & $1^{\mathrm{a}}$ & 0 \\
\hline S. Typhi CMCC 50098 & $1^{\mathrm{a}}$ & 0 \\
\hline S. Typhimurium AS1.1174 & $1^{\mathrm{a}}$ & 0 \\
\hline S. Typhimurium CMCC50180 & $1^{\mathrm{a}}$ & 0 \\
\hline Escherichia coli O157:H7 ATCC43889 & $1^{\mathrm{a}}$ & 0 \\
\hline Escherichia coli & $8^{c}$ & 0 \\
\hline Hemoclastic Escherichia coli & $1^{\mathrm{c}}$ & 0 \\
\hline Listeria monocytogenes ATCC7644 & $1^{\mathrm{a}}$ & 0 \\
\hline L. monocytogenes ATCC27708 & $1^{\mathrm{a}}$ & 0 \\
\hline L. monocytogenes ATCC54002 & $1^{\mathrm{a}}$ & 0 \\
\hline L. monocytogenes ATCCBAA-751 & $1^{\mathrm{a}}$ & 0 \\
\hline L. monocytogenes ATCC15313 & $1^{\mathrm{a}}$ & 0 \\
\hline L. monocytogenes ATCC13932 & $1^{\mathrm{a}}$ & 0 \\
\hline L. monocytogenes ATCC21-AB & $1^{\mathrm{a}}$ & 0 \\
\hline L. monocytogenes & $6^{\mathrm{c}}$ & 0 \\
\hline L. ivanovii AB 97016 & $1^{\mathrm{a}}$ & 0 \\
\hline L. innocua AB 97022 & $1^{\mathrm{a}}$ & 0 \\
\hline Enterobacter sakazakii ATCC29544 & $1^{\mathrm{a}}$ & 0 \\
\hline E. cloacae ATCC700323 & $1^{\mathrm{a}}$ & 0 \\
\hline E. cloacae ATCC 13047 & $1^{\mathrm{a}}$ & 0 \\
\hline Proteus mirabilis ATCC12453 & $1^{\mathrm{a}}$ & 0 \\
\hline P. vulgaris ATCC 33420 & $1^{\mathrm{a}}$ & 0 \\
\hline Klebsiella peneumoniae ATCC27336 & $1^{\mathrm{a}}$ & 0 \\
\hline Shigella flexneri CMCC51311 & $1^{\mathrm{a}}$ & 0 \\
\hline S. dysenteriae CMCC51335 & $1^{\mathrm{a}}$ & 0 \\
\hline Enterococcus avium ATCC 14025 & $1^{\mathrm{a}}$ & 0 \\
\hline E. faecium ATCC27270 & $1^{\mathrm{a}}$ & 0 \\
\hline E. faecalis ATCC49452 & $1^{\mathrm{a}}$ & 0 \\
\hline Citrobacter freundii ATCC8090 & $1^{\mathrm{a}}$ & 0 \\
\hline Pseudomonas aeruginosa CDC B32116 & $1^{\mathrm{a}}$ & 0 \\
\hline Serratia marcescens ATCC27592 & $1^{\mathrm{a}}$ & 0 \\
\hline Bacillus subtilis ATCC6633 & $1^{\mathrm{a}}$ & 0 \\
\hline Micrococcus luteus ATCC9341 & $1^{\mathrm{a}}$ & 0 \\
\hline Yersinia enterocolitica & $1^{\mathrm{c}}$ & 0 \\
\hline
\end{tabular}

${ }^{a}$ Standard strains were kindly provided by Shanghai Entry-Exit Inspection and Quarantine Bureau (Shanghai, China) or purchased from American Type Culture Collection and China Medical Culture Collection.

${ }^{b}$ Isolates were kindly provided by Shanghai Entry-Exit Inspection and Quarantine Bureau (Shanghai, China) and Ningbo Entry-Exit Inspection and Quarantine Bureau (Zhejiang, China).

${ }^{c}$ Other bacterial strains were acquired from our laboratory, Shanghai Jiao Tong University, Shanghai, China.

*Vibrio group I freshwater subgroup. 
Table 2 Effect of background bacterial DNA on the sensitivity of detection of $V$. parahaemolyticus DNA

\begin{tabular}{lcc}
\hline Genomic DNA concentrations & With no background non-specific DNA Ct $(\mathrm{dR})$ & With $2.1 \mu \mathrm{g}$ of background non-specific DNA Ct $(\mathrm{dR})^{*}$ \\
\hline $2.4 \mathrm{ng} / \mu \mathrm{L}$ & $18.93 \pm 0.15$ & $19.6 \pm 0.11$ \\
$240.0 \mathrm{pg} / \mu \mathrm{L}$ & $22.19 \pm 0.83$ & $22.91 \pm 0.23$ \\
$24.0 \mathrm{pg} / \mu \mathrm{L}$ & $25.96 \pm 0.11$ & $26.37 \pm 0.82$ \\
$2.4 \mathrm{pg} / \mu \mathrm{L}$ & $29.26 \pm 0.64$ & $29.57 \pm 0.13$ \\
$240.0 \mathrm{fg} / \mu \mathrm{L}$ & $32.63 \pm 0.01$ & $33.14 \pm 0.22$ \\
$24.0 \mathrm{fg} / \mu \mathrm{L}$ & $36.28 \pm 0.28$ & $37.26 \pm 0.32$ \\
$2.4 \mathrm{fg} / \mu \mathrm{L}$ & $37.78 \pm 1.06$ & $38.4 \pm 0.66$ \\
$0.24 \mathrm{fg} / \mu \mathrm{L}$ & No Ct & No Ct \\
Negative control & No Ct & No Ct
\end{tabular}

${ }^{*} F$ test analysis indicates there was no significant difference between with and without $2.1 \mu \mathrm{g}$ of background non-V. parahaemolyticus DNA in $\mathrm{C}_{\mathrm{t}}$ values $(F=0.051, p=0.825, p>0.05)$.

Table 3 Effect of background bacteria on the sensitivity of detection of $V$. parahaemolyticus in pure culture

\begin{tabular}{|c|c|c|c|}
\hline $\begin{array}{l}\text { V. parahaemolyticus concentra- } \\
\text { tions }(\mathrm{CFU} / \mathrm{mL})\end{array}$ & $\begin{array}{l}\text { With no background non- } \\
\text { specific bacteria } \\
C_{t}(d R)\end{array}$ & $\begin{array}{l}\text { With a level of } 10^{\prime} \mathrm{CFU} \text { of } \\
\text { background non-specific bacteria } \\
\mathrm{C}_{\mathrm{t}}(\mathrm{dR})^{*}\end{array}$ & $\begin{array}{l}\text { With a level of } 10^{9} \mathrm{CFU} \text { of } \\
\text { background non-specific bacteria } \\
\mathrm{C}_{\mathrm{t}}(\mathrm{dR})\end{array}$ \\
\hline $1.61 \times 10^{7}$ & $21.28 \pm 0.11$ & $23.14 \pm 0.23$ & $23.76 \pm 0.21$ \\
\hline $1.61 \times 10^{6}$ & $22.56 \pm 0.13$ & $26.01 \pm 0.14$ & $27.80 \pm 0.18$ \\
\hline $1.61 \times 10^{5}$ & $26.42 \pm 0.09$ & $30.81 \pm 0.11$ & $32.01 \pm 0.16$ \\
\hline $1.61 \times 10^{4}$ & $29.77 \pm 0.15$ & $33.86 \pm 0.06$ & $34.82 \pm 0.11$ \\
\hline $1.61 \times 10^{3}$ & $32.81 \pm 0.14$ & $37.85 \pm 0.02$ & $38.75 \pm 0.08$ \\
\hline $1.61 \times 10^{2}$ & $36.07 \pm 0.26$ & $39.95 \pm 0.01$ & No $C_{t}$ \\
\hline $1.61 \times 10^{1}$ & No $C_{t}$ & No $C_{t}$ & No $C_{t}$ \\
\hline Negative control & No $C_{t}$ & No $C_{t}$ & No $C_{t}$ \\
\hline
\end{tabular}

${ }^{*} F$ test indicates there was no significant difference between with and without a level of $10^{7} \mathrm{CFU}$ of background non-target bacteria in $\mathrm{Ct}$ values $(F=0.379, p=0.553, p>0.05)$.

Table 4 Real time PCR results of seafood samples

\begin{tabular}{lccccc}
\hline Food samples & Number & Traditional culture method $\left(\mathrm{P}^{*} / \mathrm{N}^{*}\right)$ & $\begin{array}{l}\text { Positive results } \\
(n)\end{array}$ & $\begin{array}{l}\text { Negative results } \\
(n)\end{array}$ & $\begin{array}{c}\text { False-negative results } \\
(n)\end{array}$ \\
\hline Shrimp & 37 & $18 / 19$ & 26 & 11 & 0 \\
Fish & 34 & $2 / 32$ & 8 & 22 & 4 \\
Crab & 15 & $13 / 2$ & 14 & 1 & 0 \\
Mussels & 10 & $6 / 4$ & 7 & 36 & 1 \\
Total & 96 & $39 / 57$ & 55 & 36 & 5 \\
\hline
\end{tabular}

* $P$ : positive results.

${ }^{\#} \mathrm{~N}$ : negative results.

ognition sequences as the target DNA, but with a different probe hybridization site. Two probes labeled with distinct reporter dyes (FAM and HEX) were used to differentiate target DNA and IAC amplification, and the concentration of the IAC templates was optimized. As shown in Table 5, high concentrations of IAC inhibited the amplification signal of low concentration target DNA, whereas the two lowest IAC concentrations were not sufficient to produce desired IAC amplification signal. The results showed that less than 94 copies of IAC per reaction had no influence on the detection limit of the target reaction.
The detection limit of this real time PCR system was 4.8 $\mathrm{fg} / \mathrm{PCR}$ with genomic DNA or $1 \mathrm{CFU} / \mathrm{PCR}$ for pure culture of $V$. parahaemolyticus, which is more sensitive than previously reported (4 pg and 5 CFU/PCR, 200 pg and 30 CFU/PCR, 0.17 pg/PCR) (Venkateswaran et al., 1998; Wardet al., 2006; Yu et al., 2010). Moreover, the sensitivity of the reaction was still not influenced even at high concentrations of DNA $(2.1 \mu \mathrm{g}$ per reaction) or bacterial cells $\left(10^{7} \mathrm{CFU}\right.$ per reaction). Inhibition was not observed until the level of background bacteria was increased to $10^{9} \mathrm{CFU}$ per reaction (Table 3 ). The results indicate that this real time PCR is highly sensitive and can be 
Table 5 Effect of adding different concentrations of IAC on the sensitivity of detection of $V$. parahaemolyticus purified genomic DNA

\begin{tabular}{|c|c|c|c|}
\hline Genomic DNA concentrations & Without IAC Ct (dR) & $\begin{array}{l}\text { Adding } 188 \text { copies/PCR of IAC Ct } \\
(\mathrm{dR})\end{array}$ & $\begin{array}{l}\text { Adding } 94 \text { copies/PCR of IAC Ct } \\
(\mathrm{dR})^{*}\end{array}$ \\
\hline $2.4 \mathrm{ng} / \mu \mathrm{L}$ & $18.93 \pm 0.15$ & $19.03 \pm 0.16$ & $18.83 \pm 0.42$ \\
\hline $240.0 \mathrm{pg} / \mu \mathrm{L}$ & $22.19 \pm 0.83$ & $22.41 \pm 0.92$ & $21.81 \pm 0.98$ \\
\hline $24.0 \mathrm{pg} / \mu \mathrm{L}$ & $25.96 \pm 0.11$ & $26.50 \pm 0.56$ & $25.68 \pm 0.55$ \\
\hline $2.4 \mathrm{pg} / \mu \mathrm{L}$ & $29.26 \pm 0.64$ & $29.71 \pm 0.73$ & $28.91 \pm 0.78$ \\
\hline $240.0 \mathrm{fg} / \mu \mathrm{L}$ & $32.63 \pm 0.01$ & $33.47 \pm 0.55$ & $32.47 \pm 0.67$ \\
\hline $24.0 \mathrm{fg} / \mu \mathrm{L}$ & $36.28 \pm 0.28$ & No Ct & $36.15 \pm 0.86$ \\
\hline $2.4 \mathrm{fg} / \mu \mathrm{L}$ & $37.78 \pm 1.06$ & No Ct & $39.54 \pm 0.64$ \\
\hline $0.24 \mathrm{fg} / \mu \mathrm{L}$ & No Ct & No $C_{t}$ & No Ct \\
\hline Negative control & No Ct & No Ct & No Ct \\
\hline
\end{tabular}

${ }^{*} F$ test analysis indicates there was no significant difference between with and without 94 copies $/ \mathrm{PCR}$ of IAC in $C_{t}$ values $(F=0.199, p=0.664$, $p>0.05)$.

used for successful detection with a relatively high level of background noise.

The TaqMan real time PCR assay was developed and evaluated using a novel target gene with an IAC to indicate false-negative results for the detection of $V$. parahaemolyticus in seafood samples. Five of 96 seafood samples were considered false-negative due to the lack of the IAC signal. These false-negative samples were 5 -fold serially diluted to $10^{-3}$, and $V$. parahaemolyticus was detected in 3 samples in which inhibition was no longer present. Even though inhibition was infrequent, these results demonstrated that the reliability of the PCR assay can be raised by the inclusion of an internal control.

In conclusion, this real time PCR detection system using a novel target gene with a competitive IAC was a highly specific (only positive for $V$. parahaemolyticus strains), sensitive ( $4.8 \mathrm{fg}$ of purified genomic DNA and about $1 \mathrm{CFU}$ from a pure culture per reaction), rapid (approximately $12 \mathrm{~h}$ including time for sample enrichment), accurate (able to distinguish falsenegative from true negative results), and efficient (an improvement by $19.79 \%$ compared to traditional cultural methods) method for the detection of $V$. parahaemolyticus in seafood. The multiplex assay developed herein appears to be a promising tool for high-throughput screening of food samples for V. parahaemolyticus.

\section{MATERIALS AND METHODS}

\section{Bacterial culture and DNA extraction}

A total of 390 bacterial strains were used in this study (Table 1), including $2 \mathrm{~V}$. parahaemolyticus standard strains (ATCC33846 and ATCC17802), $307 \mathrm{~V}$. parahaemolyticus isolates and 81 non-V. parahaemolyticus strains. All Vibrio species were cultured in Luria-Bertani (LB) broth with $2 \%$ sodium chloride, while the other bacterial strains were cultured in LB or Tryptone Soya Broth (TSB), or
Brain Heart Infusion (BHI). The strains were incubated at $37^{\circ} \mathrm{C}$ for 8-12 $\mathrm{h}$ with shaking at $150 \mathrm{rpm}$, and then the total genomic DNAs of different strains were extracted according to methods described by Nichols et al. (2003). DNA concentrations were determined by a spectrophotometer (DU-800 Spectrophotometer, Beckman Coulter, Fullerton, CA, USA).

\section{Primer and probe}

To identify species specific sequences for $V$. parahaemolyticus, bioinformatic methods were employed to compare genomic sequences of $V$. parahaemolyticus with all other prokaryotic genomes (Zhu et al., 2009). After evaluating the specificity both by on-line BLAST (Basic Local Alignment Search Tool) and PCR amplification and the sensitivity by PCR amplification, a species specific CDS (VP1332), encoding a putative binding protein component of the ABC transporter (Makino et al., 2003), was selected as the target gene for $V$. parahaemolyticus detection. The primers were designed using the Primer Premier 5.0 software (Premier Biosoft International, Palo Alto, CA, USA), and the probe was designed by TaKaRa Biotechnology (Dalian, China), tagged with FAM. Both primers and the probe were synthesized by TaKaRa Biotechnology (Dalian, China).

\section{IAC construction}

The IAC was constructed using PCR as previously reported (Sachadyn and Kur, 1998; Abdulmawjood et al., 2002; Wieczorek and Osek, 2004; Rodríguez-Lózaro et al., 2005). Briefly, a region of the VPA0739 gene (Makino et al., 2003) of V. parahaemolyticus was selected as IAC and its DNA sequence was not homologous with the target gene (the homologous sequence was less than $20 \mathrm{bp}$ ). Firstly, the VPA0739 gene was amplified by a long primer set, of which the 3' end sequences corresponded to the IAC primer set whereas the $5^{\prime}$ hanging end sequences corresponded to the VP1332 primer set (Table 6). Then, the 218 bp PCR product, including the flanking regions of the target primer set, was cloned into a plasmid vector pMD18-T (TaKaRa Biotechnology, Dalian, China) and sequenced for verification. Primer and probe sequences are listed in Table 6 . The 
IAC probe was labeled with HEX (Fig. 1).

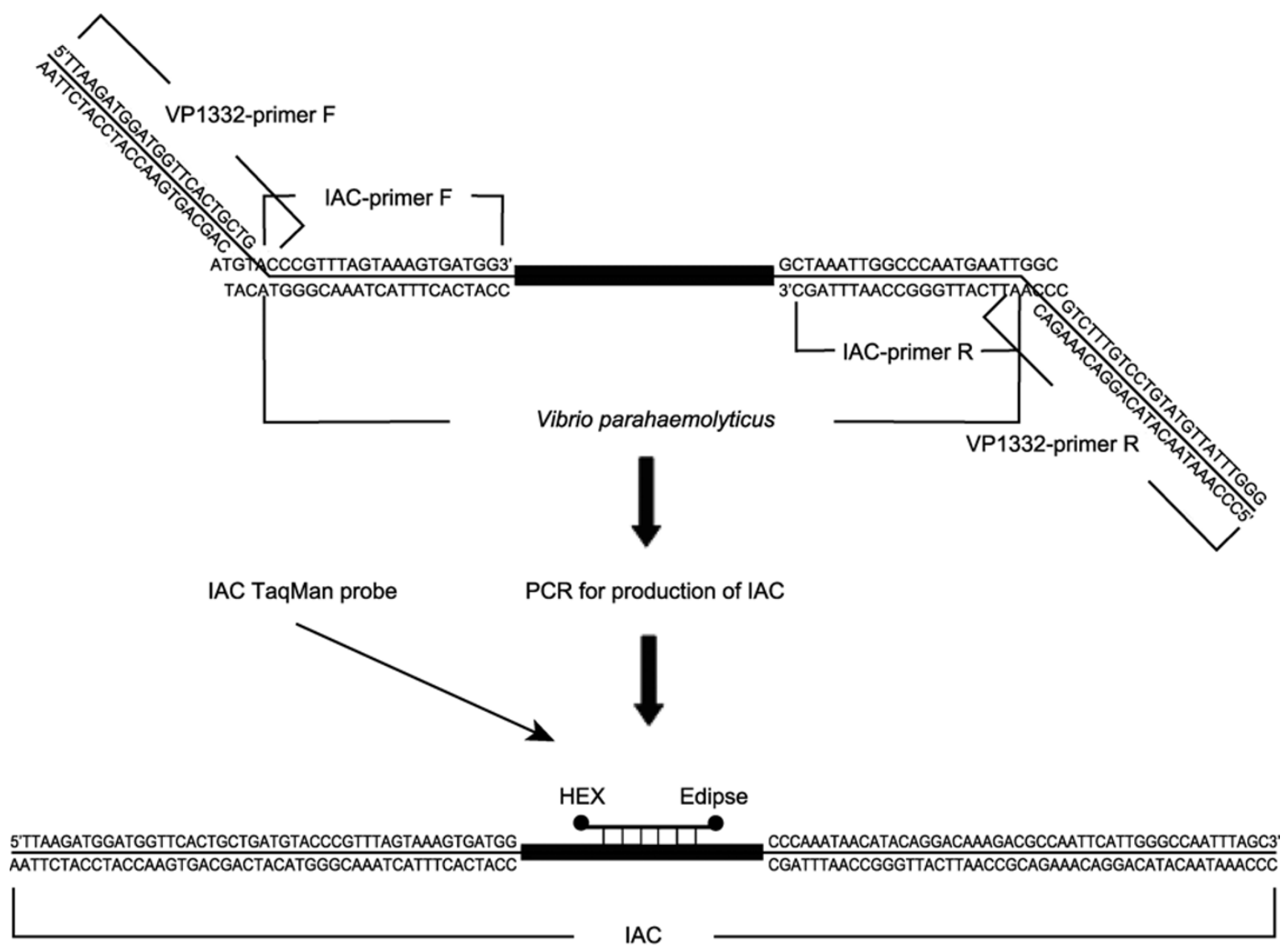

Figure 1. Scheme for construction of the IAC by compound primers technology.

Table 6 Sequences of primers and probes utilized

\begin{tabular}{|c|c|}
\hline Names & Sequences \\
\hline \multicolumn{2}{|l|}{ Primers } \\
\hline vp1332PF & 5'-TTAAGATGGATGGTTCACTGCTG-3' \\
\hline vp1332PR & 5'-GGGTTTATTGTATGTCCTGTTTCTG-3' \\
\hline IAC-primer F & 5'- ATGTACCCGTTTAGTAAAGTGATGG-3' \\
\hline IAC-primer R & 5'-CGGTTAAGTAACCCGGTTAAATCG-3' \\
\hline Long primer $\mathrm{F}^{*}$ & 5'-TTAAGATGGATGGTTCACTGCTGATGTACCCGTTTAGTAAAGTGATGG-3' \\
\hline Long primer $\mathrm{R}^{*}$ & 5'-GGGTTTATTGTATGTCCTGTTTCTGCGGTTAAGTAACCCGGTTAAATCG-3' \\
\hline \multicolumn{2}{|l|}{ Probes } \\
\hline vp1332-probe & 5'-(FAM $\left.{ }^{\mathrm{a}}\right)$ ACGCCAAACCGAACCTTTCTGCTGA (Eclipse)-3' \\
\hline IAC-probe & 5'-(HEX ') ACATTCGTCAGTGCCGTCGCCAGA (Eclipse)-3' \\
\hline
\end{tabular}

* The underlined letters are derived from the diagnostic primers.

${ }^{a}$ 6-carboxyfluorescein.

${ }^{\mathrm{b}} 5$-hexachlorofluorescein.

\section{Real time PCR amplification}

The real time PCR assays were performed using a Stratagene M×3005P ${ }^{\text {тM }}$ Quantitative PCR System (Strategene, La Jolla, CA,
USA). The final reaction volume $(25 \mu \mathrm{L})$ consisted of $1 \times$ Taq buffer $\left(\mathrm{Mg}^{2+}\right.$ plus, $\left.20 \mathrm{mmol} / \mathrm{L}\right), 0.1 \mathrm{mmol} / \mathrm{L}$ dNTPs, $0.2 \mathrm{mmol} / \mathrm{L}$ of each primer, $1 \mathrm{U}$ of Ex Taq HS DNA polymerase (TaKaRa Biotechnology, Dalian, China), $2 \mu \mathrm{L}$ of template DNA, $300 \mathrm{nmol} / \mathrm{L}$ of $\mathrm{vp} 1332$-probe, 
and $200 \mathrm{nmol} / \mathrm{L}$ of IAC-probe. All real time PCR assays were performed in triplicate using the following program: $95^{\circ} \mathrm{C}$ for $2 \mathrm{~min}$, followed by 40 cycles of $95^{\circ} \mathrm{C}$ for $10 \mathrm{~s}$, and $60^{\circ} \mathrm{C}$ for $30 \mathrm{~s}$.

\section{PCR specificity and sensitivity}

Specificity of the real time PCR assay was tested using genomic DNA from a panel of 390 bacterial strains (Table 1[A16]). For sensitivity testing, purified genomic DNA and pure culture of $V$. parahaemolyticus ATCC33846 was 10 -fold serially diluted in sterile water to $10^{-9}$. The DNA of pure culture was extracted using the boiling lysis method (Ward and Bej, 2006). The real time PCR was then carried out twice in triplicate.

\section{Standard curve for real time PCR assay}

PCR amplification efficiency, detection sensitivity and quantitative capabilities were determined using a series of 10 -fold dilutions of genomic DNA and pure culture from $V$. parahaemolyticus standard strain (ATCC33846) with predetermined DNA and cell concentrations. The amplification efficiency was calculated from the formula $E=$ $\left(10^{-1 / \text { slope }}\right)-1$ using the slopes based on standard linear curves plotted from cycle thresholds and the $\log _{10}$ values of genomic copies of each DNA per reaction. The linear regression was calculated using the MxPro ${ }^{\mathrm{TM}}$ QPCR Software (Strategene, La Jolla, CA, USA).

\section{Detection of $V$. parahaemolyticus in the background of non-V. parahaemolyticus}

The ability of the assay to detect known detectable amounts of $V$. parahaemolyticus DNA (2.4 ng-0.24 fg) in the presence of non- $V$. parahaemolyticus DNA was evaluated by adding serial dilutions of mixed genomic DNA (21.4 ng to $2.1 \mu \mathrm{g}$ ) from five bacterial strains ( $V$. vulnificus ATCC27562, V. harveyi ATCC33842, V. campbellii ATCC33863, V. fluvialis ATCC33810 and SGL) to the PCR system. All the data were analyzed using SPSS 16.0 software (SPSS, Inc, Chicago, IL, USA).

The detection capability of $V$. parahaemolyticus in the background of other Vibrio species was also evaluated by mixing their exponential phase cultures. The $V$. parahaemolyticus cultures were 10 -fold serially diluted to $10^{-9}$ in sterile water. A mixture containing equal amounts (approximately $10^{5}, 10^{7}$ or $10^{9} \mathrm{CFU}$ per reaction) of $\mathrm{V}$. vulnificus cultures, $V$. alginolyticus cultures, and $V$. harveyi cultures was added as background bacteria to each dilution (Fig. 2[A17]). DNA extraction was performed by boiling lysis method (Ward and Bej, 2006). All the data were analyzed using SPSS 16.0 software.

\section{Examination of seafood samples}

\section{Sample collection}

Ninety-six seafood samples were collected from a local market or supermarket, stored at $4^{\circ} \mathrm{C}$, and tested within $24 \mathrm{~h}$ after purchasing.

\section{Sample preparation}

All the samples were treated according to the ISO/PDTS 21872-1 draft dated November, 29th 2004 and the National Standard Method

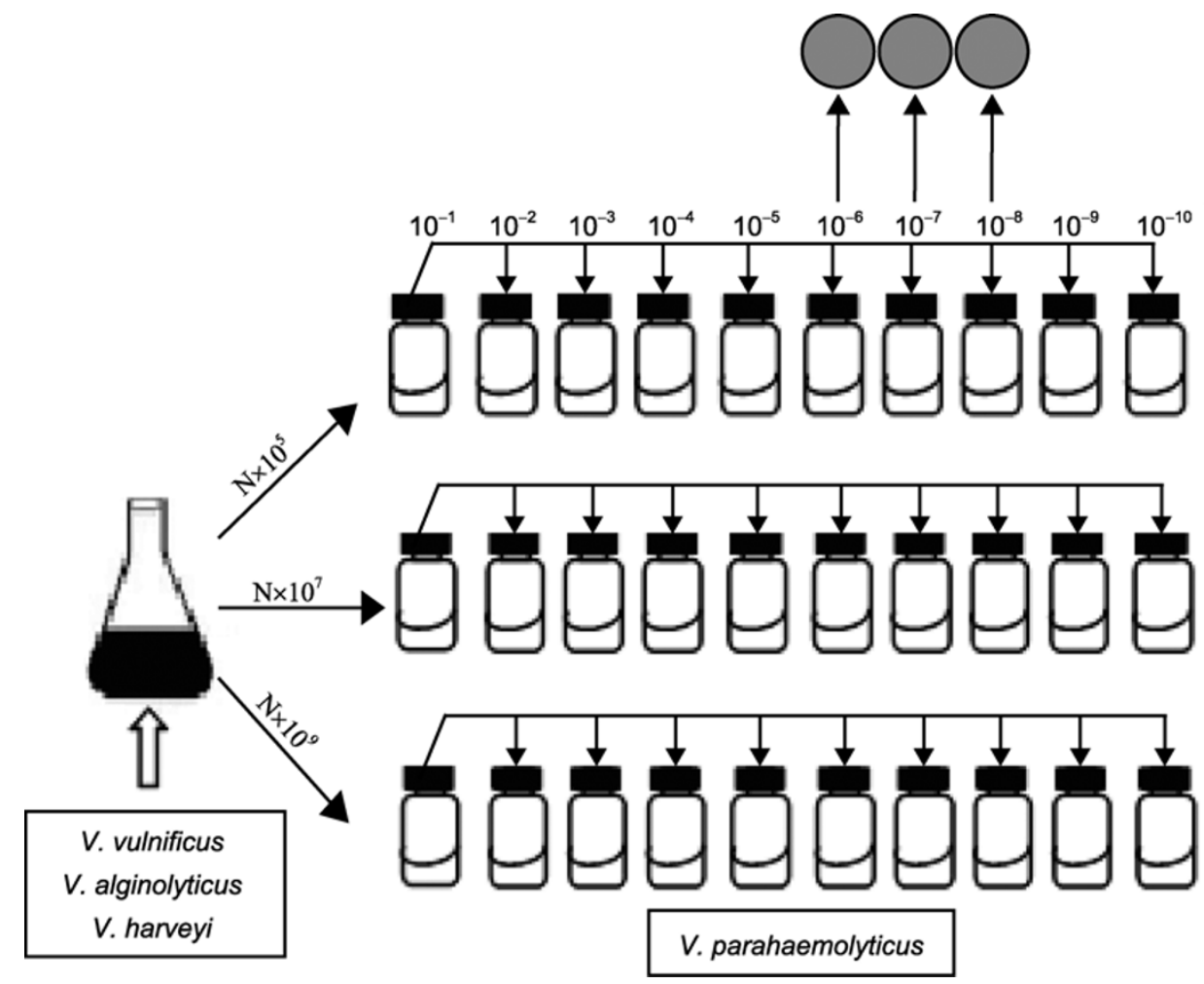


Figure 2. Scheme for determining the presence of background bacteria on detection of V. parahaemolyticus.

of China (Microbiological examination of food hygiene-Examination of V. parahaemolyticus (GB/T 4789.7--2008)) with slight modifications. Oysters were scrubbed and shucked. The entire shell contents (animal and liquor) were shucked and homogenized at a high speed for $90 \mathrm{~s}$ with a sterile blender. Ten grams of homogenate were added to $90 \mathrm{~mL}$ of alkaline peptone water (APW; $1 \%$ peptone, $3.5 \% \mathrm{NaCl}, \mathrm{pH}$ $8.5 \pm 0.2)$ in each of three separate flasks. All the samples were incubated for $10 \mathrm{~h}$ in a rotary shaker at $150 \mathrm{rpm}$ and $30^{\circ} \mathrm{C}$.

\section{Culture isolation}

After being incubated, the enrichments were streaked onto thiosulfate-citrate-bile salts-sucrose (TCBS; Difco, Sparks, MD, USA) plates and incubated overnight at $(37 \pm 1)^{\circ} \mathrm{C}$. Suspicious colonies (typically blue-green) were streaked onto non-selective media (TSB with an additional $2.5 \% \mathrm{NaCl}$ added) and were subjected to further biochemical identification, including oxidase, TSI (with an additional $2.5 \% \mathrm{NaCl}$ added), and salt tolerance tests. Suspicious V. parahaemolyticus isolates were finally confirmed by using an API $20 \mathrm{E}$ assay (bioMérieux Inc., Durham, NC, USA).

\section{DNA extraction and real time PCR detection}

After incubation in APW (2.5\% NaCl added), one milliliter portion from each sample was removed and put into a sterile $1.5 \mathrm{~mL}$ centrifuge tube and centrifuged for $10 \mathrm{~min}$ at $12,000 \mathrm{rpm}$, rinsed with sterile water and treated by the boiling lysis method for DNA extraction. Two microliters of the extracted DNA were used for real time PCR amplification.

\section{ACKNOWLEDGEMENTS}

This work was jointly supported by grants from the Ministry of Science and Technology of China (Nos. 2012AA101601 and 2011DFA31220), the National Natural Science Foundation of China (Grant Nos. 31171690, 30972485, 31000779 and U1031003) and the Science and Technology Commission of Shanghai Municipality (Nos. 10DZ0503500 and 10142201300).

\section{REFERENCES}

Abdulmawjood, A., Roth, S., and Bülte, M. (2002). Two methods for construction of internal amplification controls for the detection of Escherichia coli 0157 by polymerase chain reaction. Mol Cell Probes 16, 335-339.

Abu Al-Soud, W., and Râdström, P. (1998). Capacity of nine thermostable DNA polymerases To mediate DNA amplification in the presence of PCR-inhibiting samples. Appl Environ Microbiol 64, 3748-3753.

Al-Soud, W.A., and Rådström, P. (2001). Purification and characterization of PCR-inhibitory components in blood cells. J Clin Microbiol 39, 485-493.

Bej, A.K., Patterson, D.P., Brasher, C.W., Vickery, M.C., Jones, D.D., and Kaysner, C.A. (1999). Detection of total and hemolysin-producing Vibrio parahaemolyticus in shellfish using multiplex PCR amplification of $t l, t d h$ and trh. J Microbiol Methods 36, 215-225.

Blackstone, G.M., Nordstrom, J.L., Bowen, M.D., Meyer, R.F., Imbro, P., and DePaola, A. (2007). Use of a real time PCR assay for detection of the ctxA gene of Vibrio cholerae in an environmental survey of Mobile Bay. J Microbiol Methods 68, 254-259.

Courtney, B.C., Smith, M.M., and Henchal, E.A. (1999). Development of internal controls for probe-based nucleic acid diagnostic assays. Anal Biochem 270, 249-256.

Hartman, L.J., Coyne, S.R., and Norwood, D.A. (2005). Development of a novel internal positive control for Taqman based assays. Mol Cell Probes 19, 51-59.

Hoorfar, J., Malorny, B., Abdulmawjood, A., Cook, N., Wagner, M., and Fach, P. (2004). Practical considerations in design of internal amplification controls for diagnostic PCR assays. J Clin Microbiol 42, 1863-1868.

Hossain, M.T., Kim, E.Y., Kim, Y.R., Kim, D.G., and Kong, I.S. (2012). Application of groEL gene for the species-specific detection of $\mathrm{Vi-}$ brio parahaemolyticus by PCR. Lett Appl Microbiol 54, 67-72.

Kim, Y.B., Okuda, J., Matsumoto, C., Takahashi, N., Hashimoto, S., and Nishibuchi, M. (1999). Identification of Vibrio parahaemolyticus strains at the species level by PCR targeted to the toxR gene. J Clin Microbiol 37, 1173-1177.

Kreader, C.A. (1996). Relief of amplification inhibition in PCR with bovine serum albumin or T4 gene 32 protein. Appl Environ Microbiol 62, 1102-1106.

Luan, X.Y., Chen, J.X., Zhang, X.H., Jia, J.T., Sun, F.R., and Li, Y. (2007). Comparison of different primers for rapid detection of $\mathrm{Vi-}$ brio parahaemolyticus using the polymerase chain reaction. Lett Appl Microbiol 44, 242-247.

Maaroufi, Y., Ahariz, N., Husson, M., and Crokaert, F. (2004). Comparison of different methods of isolation of DNA of commonly encountered Candida species and its quantitation by using a real-time PCR-based assay. J Clin Microbiol 42, 3159-3163.

Maaroufi, Y., de Bruyne, J.M., Duchateau, V., Scheen, R., and Crokaert, F. (2006). Development of a multiple internal control for clinical diagnostic real-time amplification assays. FEMS Immunol Med Microbiol 48, 183-191.

Makino, K., Oshima, K., Kurokawa, K., Yokoyama, K., Uda, T., Tagomori, K., lijima, Y., Najima, M., Nakano, M., Yamashita, A., et al. (2003). Genome sequence of Vibrio parahaemolyticus: a pathogenic mechanism distinct from that of $V$. cholerae. Lancet 361, 743-749.

Miller, V.L., Taylor, R.K., and Mekalanos, J.J. (1987). Cholera toxin transcriptional activator toxR is a transmembrane DNA binding protein. Cell 48, 271-279.

Nichols, R.A., Campbell, B.M., and Smith, H.V. (2003). Identification of Cryptosporidium spp. oocysts in United Kingdom noncarbonated natural mineral waters and drinking waters by using a modified nested PCR-restriction fragment length polymorphism assay. Appl Environ Microbiol 69, 4183-4189. 
Niesters, H.G. (2004). Molecular and diagnostic clinical virology in real time. Clin Microbiol Infect 10, 5-11.

Nordstrom, J.L., Vickery, M.C., Blackstone, G.M., Murray, S.L., and DePaola, A. (2007). Development of a multiplex real-time PCR assay with an internal amplification control for the detection of total and pathogenic Vibrio parahaemolyticus bacteria in oysters. Appl Environ Microbiol 73, 5840-5847.

Raggam, R.B., Leitner, E., Berg, J., Mühlbauer, G., Marth, E., and Kessler, H.H. (2005). Single-run, parallel detection of DNA from three pneumonia-producing bacteria by real-time polymerase chain reaction. J Mol Diagn 7, 133-138.

Rodríguez-Lázaro, D., Pla, M., Scortti, M., Monzó, H.J., and Vázquez-Boland, J.A. (2005). A novel real-time PCR for Listeria monocytogenes that monitors analytical performance via an internal amplification control. Appl Environ Microbiol 71, 9008-9012.

Rosenstraus, M., Wang, Z., Chang, S.Y., DeBonville, D., and Spadoro, J.P. (1998). An internal control for routine diagnostic PCR: design, properties, and effect on clinical performance. J Clin Microbiol 36, 191-197.

Sachadyn, P., and Kur, J. (1998). The construction and use of a PCR internal control. Mol Cell Probes 12, 259-262.

Shirai, H., Ito, H., Hirayama, T., Nakamoto, Y., Nakabayashi, N., Kumagai, K., Takeda, Y., and Nishibuchi, M. (1990). Molecular epidemiologic evidence for association of thermostable direct hemolysin (TDH) and TDH-related hemolysin of Vibrio parahaemolyticus with gastroenteritis. Infect Immun 58, 3568-3573.

Tada, J., Ohashi, T., Nishimura, N., Shirasaki, Y., Ozaki, H., Fuku- shima, S., Takano, J., Nishibuchi, M., and Takeda, Y. (1992). Detection of the thermostable direct hemolysin gene $(t d h)$ and the thermostable direct hemolysin-related hemolysin gene (trh) of Vibrio parahaemolyticus by polymerase chain reaction. Mol Cell Probes 6, 477-487.

Venkateswaran, K., Dohmoto, N., and Harayama, S. (1998). Cloning and nucleotide sequence of the gyrB gene of Vibrio parahaemolyticus and its application in detection of this pathogen in shrimp. Appl Environ Microbiol 64, 681-687.

Wang, S., Duan, H., Zhang, W., and Li, J.W. (2007). Analysis of bacterial foodborne disease outbreaks in China between 1994 and 2005. FEMS Immunol Med Microbiol 51, 8-13.

Ward, L.N., and Bej, A.K. (2006). Detection of Vibrio parahaemolyticus in shellfish by use of multiplexed real-time PCR with TaqMan fluorescent probes. Appl Environ Microbiol 72, 2031-2042.

Wieczorek, K., and Osek, J. (2004). Development of a PCR internal amplification control for the detection of Shiga toxin-producing Escherichia coli. Bulletin Veterinary Institute Pulawy 48, 397-401.

Yu, S., Chen, W., Wang, D., He, X., Zhu, X., and Shi, X. (2010). Species-specific PCR detection of the food-borne pathogen Vibrio parahaemolyticus using the irgB gene identified by comparative genomic analysis. FEMS Microbiol Lett 307, 65-71.

Zhu, D.S., Zhou, M., Fan, Y.L., and Shi, X.M. (2009). Identification of new target sequences for PCR detection of Vibrio parahaemolyticus by genome comparison. J Rapid Meth Automation Microbiol 17, 67-79. 